THOMAS LUX is 27 years old, and currently teaches poetry workshops at Columbia College in Chicago. His poems have appeared in Field, New American Review, and many other magazines. His first book, Memory's Handgrenade, was published in 1972 by Pym-Randall Press.

\title{
THERE ARE MANY THINGS THAT PLEASE ME
}

The loam and lungs of dreams to begin with. Certainly those sailboats drifting across your thighs please me. I'm pleased with the courage of the surgeon who performs open heart surgery on a mosquito and I'm so pleased I can hardly describe the courage of the mosquito. I'm pleased that ice is finally beginning to lose. I'm pleased, very pleased, with the lizards and fish and whoever else taught us this language. Nothing pleases me more than not having my tongue drawn back in terror. I'm even pleased with my strength: I can lift these gray aspirin to my lips, I can tear this match from a matchbook. I'm pleased we can say to our children: It's almost time to sing! All these things please me, so many things please me. I'm pleased in the evening when I lower the shade and what looks like the last snowflake in the world doesn't float by. . . . But most of all I'm pleased with myself, pleased with myself in the same way I'd be pleased with a man who carries with him a sack of disdain, a somewhat silver 
disdain, nevertheless a disdain, and who is beginning to spill it, spill it in the same way the sun climbs a hill early in the morning: gradually, with a determined heat, leaf by leaf and branch over branch.

LONGITUDE AND LATITUDE: HART CRANE

If we knew the exact longitude and latitude of the Orizaba the moment Hart jumped from the bow

we could go there and still find in the air the delicate curve his body made. It's there, you've got to believe me! And Hart's still around, probably smooth and calm in some current travelling

the Gulf Stream, or else swimming occasionally up river into America, close to the banks, close, close. 